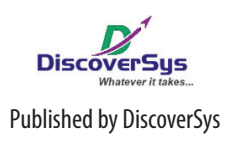

Published by DiscoverSys

\section{Switching of primary health care providers among self-paid health insurance participants in Denpasar, Bali, Indonesia}

Rai Riska Resty Wasita, ${ }^{*}$ Ni Made Sri Nopiyani, ${ }^{2}$ Pande Putu Januraga ${ }^{2}$

\section{ABSTRACT}

Background and purpose: The number of National Health Insurance (NHI) participants switching their primary healthcare (PHC) providers is increasing and dominated by self-paid participants. This switching could result in unequal distribution of NHI participants and amount of capitation among PHC providers. This study aims to explore the reasons underlying self-paid NHI participants to switch PHC providers.

Methods: This is a qualitative study using in-depth interviews with a total of 14 informants recruited purposively, consisted of ten NHI selfpaid participants who had switched and four participants who intend to switch PHC providers. Informants were recruited by approaching NHI participants at BPJS counters and inviting participants through social media. Semi-structured interview guide incorporated the aspects of Consumer Switching Behavior Model. The interviews explored four aspects of participants' intention to switch providers including inconvenience, service encounter failures, core health service failures, and attraction by competitor. The verbatim transcripts were analyzed thematically.

Results: Self-paid NHI participants in this study cited four main reasons for switching PHC providers. The first reason is inconvenience in accessing PHC provider's services due to long distance, long waiting times, unsuitable opening hours, and poor facilities. Secondly, patients cited the poor interaction between healthcare providers and patients specifically, lack of attentiveness, poor eye contact, poor delivery of health information, lack of consideration of patients' opinions, and lack of responsiveness to patients' complaints. The third reason is core healthcare service failures, including hasty examinations, inaccurate diagnoses, and errors in prescribing medication. Finally, informants reported that they wished to switch PHC providers due to the attractiveness of other providers, in terms of facilities availability, professionalism of healthcare providers, additional health programs, and ease of access to referral healthcare facilities.

Conclusion: Self-paid NHI participants' intention to switch PHC providers was mainly attributed to the perceived poor healthcare quality of the provider and superiority of the others. Continuous quality improvement should be undertaken by PHC providers to increase participants' loyalty.

Keywords: switching primary health care providers, self-paid health insurance participants

Cite This Article: Wasita, R.R.R., Nopiyani, N.M.S., Januraga, P.P. 2018. Switching of primary health care providers among self-paid health insurance participants in Denpasar, Bali, Indonesia. Public Health and Preventive Medicine Archive 6(2): 140-147. D01:10.15562/phpma.v6i2.182

${ }^{1}$ Faculty of Health Science and Technology, Dhyana Pura University, Bali,

${ }^{2}$ Department of Public Health and Preventive Medicine, Faculty of Medicine, Udayana University, Bali.

${ }^{*}$ Correspondence to: Rai Riska Resty Wasita, Faculty of Health Science and Technology, Dhyana Pura University, Bali riskaresty@gmail.com

\section{INTRODUCTION}

The Indonesian Government has implemented Jaminan Kesehatan Nasional or National Health Insurance (NHI) since $1^{\text {st }}$ of January 2014, in order to achieve universal health coverage. ${ }^{1}$ In 2017, there were 3,031,223 Bali residents registered as NHI participants, with 601,260 of them were in Denpasar. ${ }^{2,3}$ Presidential Regulation Number 19 Year 2016 Article 29 states that NHI participants are required to be registered at one $\mathrm{PHC}$ provider and have the right to choose their providers. ${ }^{4}$ In addition, they are allowed to move to another provider after being registered as participants at least for three months. ${ }^{4}$ In 2017, there were 119 PHC providers collaborating with the Implementing Agency of National Health Insurance or Badan Penyelenggara Jaminan Sosial (BPJS) Kesehatan in Denpasar, consisted of 11 public health centers or pusat kesehatan masyarakat (puskesmas), 60 private general practitioners, 22 dental practices,
19 primary healthcare clinics, 4 military clinics, and 3 police clinics. ${ }^{5}$ From June to November 2016, there were 2,844 transfer requests made by NHI participants in Denpasar, which dominated by self-paid health insurance participants. These changes could result in unequal distribution of NHI participants and amount of capitation among PHC providers, and the need for renewal of participants' Kartu Indonesia Sehat or Indonesian Health Card. ${ }^{6}$

Publications on the reasons underlying health insurance participants' intention to switch PHC providers remain limited and mostly employed quantitative study. In addition, majority of studies investigated the factors contributed to healthcare facilities switching not specifically in health insurance participants. Those studies indicated an association between switching healthcare providers and factors such as the availability of facilities, waiting times, the distance of health 
facilities, change place of residence, the quality of healthcare, opening hours, the influence of patient's peer groups, convenience, core service failures, ethical problems, forced displacement, price, age, education, patient satisfaction and loyalty to a particular healthcare provider. ${ }^{6-10}$ The current study adopts a qualitative approach to explore self-paid NHI participants' reasons underlying their decision to switch to alternative $\mathrm{PHC}$ providers.

\section{METHODS}

This is a qualitative study which data was collected through in-depth interviews in Denpasar, Bali from April to May 2018. There were a total of 14 participants recruited purposively consisting of ten self-paid NHI participants who had switched PHC providers, and four participants who intend to switch providers. The selection criteria are selfpaid NHI participants who have been registered for more than three months, and have accessed their PHC providers. Informants were recruited by approaching NHI participants at BPJS counters who met the study's selection criteria, and inviting participants through social media. Then, informant consent was obtained prior to face-to-face interview. The interviews were conducted at an agreed location, lasted an average of 45-60 minutes and audio-recorded.

Semi-structured interview guide incorporated the aspects of Consumer Switching Behavior Model. The interviews explored four aspects of patients' intention to switch PHC providers including inconvenience, service encounter failures, core health service failures and attraction by competitor. ${ }^{11}$ The records of interviews were transcribed as verbatim transcripts, which then read multiple times to familiarize with the ideas raised by the informants. Afterwards, the data were analyzed thematically with deductive approach. A priori themes emerged from Consumer Switching Behavior Model were divided into sub-themes which were then identified and coded in each of the transcripts. The internal validity of the data was ensured through triangulation by considering information from various perspectives of participants switching from public to private PHC providers and vice versa and of those from different insurance classes. This study has been approved by the Ethics Committee of the Faculty of Medicine, Udayana University/Sanglah General Hospital, Denpasar on March 23, 2018.

\section{RESULTS AND DISCUSSION Informant Characteristics}

Informant characteristics are presented in Table 1. Informants consisted of ten self-paid NHI participants who had switched PHC providers, and four participants who intend to switch providers. Their age ranged from 25 to 52 years and the majority were female. Informants were high-school to university graduates, and predominantly employed in the private sector. Informants were from first and second insurance classes and have been enrolled for one to three years. Most participants switched from puskesmas to private clinics.

\section{Reasons of switching primary healthcare providers}

The interview data highlighted four key themes motivating self-insured NHI participants in Denpasar to switch PHC providers consisted of inconvenience in accessing services, poor quality of healthcare providers and patient interactions, inaccuracies in health service provision and attractiveness of other providers. A summary of themes and sub-themes identified from the interviews is presented in Table 2.

\section{Inconvenience in accessing primary healthcare services}

A number of informants reported experiencing inconvenience in accessing their previous or current providers in terms of operating hours, the distance to reach providers, waiting times and availability of facilities. These represent the main reasons why participants decided to switch providers. The lack of suitable operating hours of their providers consisted of a non 24-hour service provision and conflicting operating hours with participant's working hours.

"I work early; I switched because the clinic's morning opening times are very limited. Also, my community obligations don't operate on a firm schedule, and so, I chose to see a private doctor because they are open in the evening." (PP-01)

Most informants consider PHC provider's operating times very important since their availability to attend a doctor's appointment is subject to working hours, social activities and unpredictable time of sickness. Informants reported their preference to providers offering a 24-hour service. This concurs with the finding of a study in Lhokseumawe, that NHI participants had a tendency to select primary healthcare facilities based on their opening hours and the availability of doctors who can be accessed at any time. ${ }^{12}$

Another key factor highlighted by the informants was the distance involved in travelling to PHC providers. Informants reported that distant providers caused difficulties in reaching them when requiring medical assistance. Also, a number of 
Table 1 Characteristics of informants

\begin{tabular}{|c|c|c|c|c|c|c|c|c|}
\hline $\begin{array}{l}\text { Code of } \\
\text { informants }\end{array}$ & $\begin{array}{c}\text { Age } \\
\text { (years) }\end{array}$ & Gender & Education & Employment & $\begin{array}{l}\text { Previous } \\
\text { providers }\end{array}$ & $\begin{array}{c}\text { Current } \\
\text { providers }\end{array}$ & $\begin{array}{c}\text { Insurance } \\
\text { Classes }\end{array}$ & $\begin{array}{l}\text { Number of } \\
\text { years in NHI }\end{array}$ \\
\hline PP-01 & 27 & $\mathrm{~F}$ & University & Teacher & Puskesmas & $\begin{array}{c}\text { General } \\
\text { practitioner }\end{array}$ & 1 & 3 \\
\hline PP-02 & 26 & $\mathrm{~F}$ & University & $\begin{array}{c}\text { Private } \\
\text { employee }\end{array}$ & $\begin{array}{c}\text { General } \\
\text { practitioner }\end{array}$ & Private clinic & 1 & 2 \\
\hline PP-03 & 25 & $\mathrm{~F}$ & University & Physician & $\begin{array}{c}\text { General } \\
\text { practitioner }\end{array}$ & Puskesmas & 1 & 1 \\
\hline PP-04 & 30 & M & University & Self-employed & Puskesmas & Private clinic & 1 & 2 \\
\hline PP-05 & 26 & $\mathrm{~F}$ & University & $\begin{array}{c}\text { Private } \\
\text { employee }\end{array}$ & Private clinic & Private clinic & 1 & 3 \\
\hline PP-06 & 26 & $\mathrm{~F}$ & University & Lecturer & Puskesmas & $\begin{array}{c}\text { General } \\
\text { practitioner }\end{array}$ & 1 & 2 \\
\hline PP-07 & 52 & $\mathrm{~F}$ & $\begin{array}{c}\text { Elementary } \\
\text { school }\end{array}$ & Housewife & Puskesmas & $\begin{array}{c}\text { General } \\
\text { practitioner }\end{array}$ & 1 & 3 \\
\hline PP-08 & 30 & M & University & $\begin{array}{c}\text { Private } \\
\text { employee }\end{array}$ & Puskesmas & Private clinic & 2 & 3 \\
\hline PP-09 & 33 & M & University & Teacher & Puskesmas & Puskesmas & 1 & 1 \\
\hline PP-10 & 29 & M & High School & Self-employed & $\begin{array}{c}\text { General } \\
\text { practitioner }\end{array}$ & Private clinic & 2 & 2 \\
\hline IP-01 & 26 & M & University & Self-employed & - & Private clinic & 2 & 2 \\
\hline IP-02 & 24 & $\mathrm{~F}$ & University & $\begin{array}{c}\text { Private } \\
\text { employee }\end{array}$ & - & Private clinic & 1 & 2 \\
\hline IP-03 & 29 & $\mathrm{~F}$ & University & Self-employed & - & Puskesmas & 1 & 3 \\
\hline IP-04 & 28 & M & High School & Self-employed & - & Puskesmas & 2 & 1 \\
\hline
\end{tabular}

Note: Informant codes: $\mathrm{PP}$ = have switched providers; IP = intend to switch providers

Table 2 Summary of the themes and sub-themes emerging from the interviews

\begin{tabular}{ll}
\hline Themes & Sub-themes \\
\hline $\begin{array}{l}\text { Inconvenience in accessing PHC } \\
\text { services }\end{array}$ & $\begin{array}{l}\text { Provider's operating hours conflict with participant's working hours, long distance to reach providers, } \\
\text { long waiting times, incomplete facilities }\end{array}$ \\
$\begin{array}{l}\text { Poor quality of doctor-patient } \\
\text { interactions }\end{array}$ & $\begin{array}{l}\text { Lack of health centre staff' attentiveness, eye contact, unclear delivery of information about treatment } \\
\text { and medication, failure to consider patient's opinions, poor responses to patients' complaints }\end{array}$ \\
$\begin{array}{l}\text { Core healthcare service failures } \\
\text { The appeal of other clinics }\end{array}$ & $\begin{array}{l}\text { Hasty examinations, inaccurate diagnoses and prescription of medication } \\
\text { Excellent facilities, health professional, range of health programs, and ease of access to referral healthcare } \\
\text { facilities }\end{array}$
\end{tabular}

informants reported they had switched from their previous providers because they had changed place of residence due to work demands and decided to switch to an easier-to-reach clinic.

\section{"Actually, I moved for work reasons. So I switched clinics to one closer to my new house." (PP-09)}

This finding is similar to other study conducted in Lhokseumawe and Lombok indicated that distance is one of the primary consideration in selecting a primary healthcare provider. ${ }^{6,12,13}$

A number of informants stated they spent over an hour to meet the doctor at their current PHC providers. Some of them even felt disadvantaged due to their lost of opportunities to perform other activities which then motivated them to switch to closer providers.

"I waited between one and two hours [to see a doctor] because there were so many patients. So, I had to write off lots of work that day." (IP-02)

When compared with standard waiting times for outpatient services (60 minutes), the waiting times reported by informants in the present study exceeded the standard. ${ }^{14}$ Further, a number of studies also show that long waiting times may raise 
patient's physical and emotional stress, negatively impact their health, and reduce the efficacy of the treatment they eventually receive. Moreover, long waiting times also indirectly contribute to lower productivity due to lost work time..$^{15}$

Another factor that participants cited for switching providers were the limited facilities offered by their previous providers, specifically inadequate parking area and waiting room space.

"The parking is terrible and the waiting room only has four seats. It's stuffy and narrow ... many people [waiting to see a doctor] wait outside so they don't get too hot" (PP-01)

The availability and quality of medical and supporting facilities represent a tangible dimension of service quality which appears to be uppermost in patient's minds when accessing healthcare and greatly affects their satisfaction levels. ${ }^{16}$ Adequate numbers and well-functioning healthcare facilities will be able to optimize patient satisfaction towards healthcare. ${ }^{17,18}$

\section{Poor quality of healthcare providers and patient interactions}

Informants reported that the poor quality of doctor-patient interactions at their previous PHC providers represents a major driver to switch providers. This includes concerns about doctors' manner when dealing with patients, clarity of information regarding the examination results, patient's involvement in decision-making about treatment options and healthcare providers' responses to patients' complaints.

All informants expressed that they wished to be greeted cordially and acknowledged by the health centre staff. However, some informants reported receiving poor service in this respect, with health staff displaying a lack of friendliness and failing to maintain eye contact during communication.

"They [the health centre staff] never smile, if I smile, they just ignore it and carry on talking without a smile." (PP-09)

"They [the health centre staff] don't look me in the eye. The doctor seems like he's too busy talking and writing to explain [about the patient's condition and treatment]". (PP-04)

In addition to concerns about the way staff dealing with patients, informants also felt that some doctors did not provide a clear explanation regarding their diagnosis and health condition during the consultation, primarily because these doctors tended to use medical terms that could not be understood by the patients.

"Sometimes doctors use medical language, so I don't understand." (PP-04)

Moreover, one informant reported that the doctor did not consider his opinion regarding referral, resulting in the informant failing to secure a referral to the hospital he requested and the doctor failed to provide an explanation for the reasons of his decision.

"I asked my doctor for a referral to a hospital X but he directed me to hospital Y. Whether the referral process is like this in reality, I don't know. But I felt that at least he [the doctor] could have explained it to me. I was really disappointed." (PP-08)

Further, another informant felt that the staff at his PHC provider were unresponsive to his needs; explaining that he was asked to sit in the examination room with the doctor who did not begin the consultation until his medical records arrived.

"The response is rather slow. I was asked to sit in the treatment room with the doctor, who did not ask me anything about my health because he was still waiting for my health records to arrive. I think that the doctor should have used this time to ask me about my symptoms and generally chat about my health. When my health records arrived, the doctor finally began asking me hastily." (IP-03)

Health workers must be multi-skilled, and besides their medical knowledge, one of the key skills in which they must be proficient is interacting and communicating with patients in a professional and effective manner in order to establish an effective therapeutic doctor-patient relationship. Patients tend to be dissatisfied with doctors with poor communication skills, which negatively impacts patient loyalty, eroding patients' trust in their doctor, which in turn, can affect patient's adherence to therapy. Therefore, one area that should be targeted to optimize patients' satisfaction is by raising their staff's ability to interact and communicate professionally and effectively. ${ }^{19-21}$ 


\section{Core healthcare service failures}

The results show that informants were concerned about three specific aspects of healthcare at PHC providers including the duration of doctor-patient consultations, the accuracy of diagnosis and the prescription of medication. These represent key factors influencing informants' decision to switch providers. A number of informants reported that consultations were carried out in a hurried fashion, which led them to feel they had not received a comprehensive health services and unable to discuss their health concerns properly with their doctor.

"The doctor did the examination as quickly as possible. When I was examined, I felt that I couldn't ask him any questions even though I still wanted to ask more about food or other restrictions." (PP-09)

Sufficient time is required to enable effective communication between doctors and patients. Limited consultation times might impact the clarity of information received by the patients. Moreover, the doctor is unlikely to be able to gather a sufficient amount of information from the patient to establish an accurate diagnosis and effective treatment plan. ${ }^{22,23}$

A number of informants in the current study also revealed their health condition had failed to improve after receiving treatment at their previous PHC providers. This had driven them to seek treatment elsewhere, in which the diagnosis is different from the previous doctor's.

"I saw a doctor at the puskesmas that morning. $\mathrm{He}$ said it was just inflammation of the skin. Then, later in the day, I began to feel weak and my skin felt really itchy. I went to a specialist - it turned out I had smallpox. I was a bit disappointed and felt a little annoyed." (IP-03)

Misdiagnosis often results in inappropriate treatment that consequently slows down patients' recovery. In addition, misdiagnosis erodes patients' trust in their doctor's medical ability and reduces patient loyalty to the clinic where they were misdiagnosed. Inaccurate diagnosis is also related to patients' views on the quality of the healthcare provided to them in terms of assurance. Therefore, healthcare providers are duty bound to provide patients with a sense of security in their treatment and ensure patients' health is not threatened by inaccurate diagnosis and prescription of inappropriate medication. ${ }^{17}$ Greater patient comfort, assurance for a successful recovery as well as doctors' ability to treat patients professionally increase patients' confidence in accessing services of PHC providers. ${ }^{17,24}$

Further, a number of informants reported having received inadequate information about how they should use medication prescribed to them. Meanwhile, another informant complained of being prescribed unsuitable medication that he decided to seek a second opinion from another doctor.

"After I had been given the medicine, there was no other communication. Just take this medication once a day, and this one three times a day and the name of my condition was written on the medication packaging. I was unsure if I had to finish the course of pills or what. They didn't clearly tell me what I should do." (PP-09)

"I took the medicine my doctor gave me for my skin inflammation - it didn't work. Instead, it got worse, my skin still hurt and was itchy. So I went to a skin specialist and he said it was chickenpox. He gave me chickenpox medicine. A few days later, it improved." (IP-03)

Providing proper, comprehensive medication information to patients is important in supporting a rational use of medication. Improper medication information can lead to irrational use of medication and negatively affect patients' treatment outcomes. ${ }^{25}$ Furthermore, it can also diminish patients' trust and loyalty to healthcare facilities. This finding is similar to study from other countries suggesting that the appropriate use of medication benefits patients in terms of recovery as well as in indirectly increasing patient trust and loyalty. ${ }^{26}$

\section{The appeal of other primary healthcare providers}

Aside from the quality-related factors discussed above, the present study also found that informants' desire to switch PHC providers was also motivated by the appeal of other providers offering superior facilities, more professional healthcare staff, a range of health programs and a closer distance to referral healthcare facilities. An informant who switched providers from general practitioner to puskesmas claimed that his decision to switch is due to the better facilities offered by puskesmas.

"In terms of facilities, puskesmas are indeed more sophisticated. They use a computerised ticket queuing system and they call patients over a loudspeaker while the general practitioner still uses the old, paper-ticket system. Also, puskesmas offer an emergency-room service so they can handle emergency cases quickly." (PP-03) 
The PHC providers collaborating with BPJS Kesehatan should have their own competitive advantages to be able to attract NHI participants. To improve their competitiveness in the NHI era, these healthcare facilities should focus on developing a quality and responsive healthcare services. Provision of adequate facilities will allow providers to provide convenient and comfortable healthcare services for the communities they serve which will enhance patient loyalty to the providers. ${ }^{27}$

Health workers' attitudes and abilities represent a key consideration affecting patients' decision to switch healthcare providers. Friendliness of staff, competent doctors and suitable opening times are among the main factors which motivated some participants in the present study to switch providers.

"The staff at the clinic where I want to move to are all friendly and smile at everyone. The standard of service is also better, much better, in fact. They have competent doctors, are open 24 hours a day, and have the doctor that I want." (IP-02)

Health workers play an important role as the gatekeepers to healthcare services. Better patientstaff interaction and better staff competency will improve patient trust in receiving treatment. This finding is consistent with studies conducted across eight large districts in Indonesia, which concur that in order to achieve public confidence in PHC providers, they must demonstrate insight, competence, and expertise, in order to cultivate patient loyalty towards health care professionals. ${ }^{28}$

The standard of healthcare services received by NHI participants at PHC providers is not only determined by the core health services offered but also by other programs that patients find appealing. A number of participants reported that they were attracted to particular providers because of the range of health-related programs they offer.

"They have exercise club for a particular disease. This is one of the attractions of this clinic. At my previous puskesmas they only offer standard examinations." (PP-01)

The growth in the number of PHC providers offering various health programs is part of a strategy to improve community trust and satisfaction. These findings are similar to a study conducted at the Puskesmas Jagir in Surabaya which found that community tend to choose interesting and innovative health programs which also meet the needs of the community. The availability of such health programs improve the attractiveness of healthcare providers. ${ }^{29}$

The location of PHC providers that close to referral healthcare facilities also drives patients to switch providers. Informants in the present study perceived that a close location of PHC to referral facilities would speed up the referral process; especially in terms of distance and travel time.

"I chose my present healthcare clinic because it is run by the hospital, so if I need a referral to a higher-level health facility, it's all under one roof." (PP-02)

"My doctor's practice is close to the hospital, so if anything were to happen [with my health] I can go straight there [hospital]. If I need to see a specialist doctor, I only have to cross the road [to access the hospital services]." (PP-06)

Informants in the present study reported that the ease of access to healthcare facilities in terms of location also adds appeal to a particular PHC providers. This finding is supported by the results of a study conducted in Gianyar, Bali, which indicates that PHC providers strategically and conveniently located close to referral healthcare facilities enhance patients' sense of comfort and safety. This is because such providers are able to meet their patients' healthcare needs and can provide a quick referral to a specialist. ${ }^{30}$

The limitation of this study is in the lack of variation of informants regarding the health insurance classes that only consisted of first and second health insurance classes. Therefore, it has not been able to describe the reasons of switching providers among third class self-paid NHI participants. Moreover, this study was conducted in Denpasar that may have different circumstance compared to other regions. Therefore, the results of this study can only be used as a theoretical reference for a similar context or situation.

\section{CONCLUSION}

The main reasons underlying self-paid NHI participants to switch PHC providers namely inconvenience in accessing healthcare services, poor-quality of doctor-patient interactions, core healthcare service failures, and the appeal of other PHC providers. Thus, continuous quality improvement should be undertaken by PHC providers to improve participants' loyalty. 


\section{ACKNOWLEDGEMENT}

We would like to thank all of the informants and BPJS Kesehatan of Denpasar who have supported this study.

\section{REFERENCES}

1. Ministry of Social Welfare of Indonesia. Peta jalan menuju Jaminan Kesehatan Nasional 2012-2019 [Roadmap towards the National Health Insurance 2012-2019]. Jakarta; 2012.

2. Bali Province Health Office. Profil Kesehatan Provinsi Bali 2017 [Bali Province 2017 Health Profile]. 2017.

3. Denpasar City Health Office. Denpasar City 2017 Health Profile. Denpasar; 2017.

4. President of the Republic of Indonesia. Peraturan Presiden no 19 Tahun 2016 Perubahan Kedua Atas Peraturan Presiden Nomor 12 Tahun 2013 Tentang Jaminan Kesehatan [The 2016 Presidential Regulation no. 19 Second Revision for the 2013 Presidential Regulation No. 12 on Health Insurance]. 2016.

5. The Indonesia National Health Insurance Implementing Board, Denpasar Branch. Cakupan jumlah peserta NHIKIS Kantor Cabang Denpasar Bulan September Tahun 2017 [The coverage of NHI-KIS participants Denpasar Branch September 2017]. Denpasar; 2017.

6. Suandana IA. Faktor-faktor yang berhubungan dengan keinginan perpindahan fasilitas kesehatan tingkat pertama pada peserta NHI Mandiri di Kota Denpasar Tahun 2017 (skripsi) [Factors associated with the intention to switch primary health care providers among self paid NHI participants in Denpasar City 2017]. Denpasar: Universitas Udayana; 2017.

7. Rachmawardani R. Analisis perilaku perpindahan jasa rumah sakit [Analysis on the behavior of switching hopitals]. 2006; (serial online) [cited 2018 Januari 5] Available from: http://etd.repository.ugm.ac.id/ index.php? mod=penelitian_detail\&sub=Peneliti anDetail\&act=view\&typ=html\&buku_id $=29888$

8. Yulfajar A, Rofiaty. Switching behavior pada konsumen klinik kecantikan di Kota Surabaya [Switching behavior among the consumers of beauty clinics in Surabaya City]. Jurnal Aplikasi Manajemen. 2011; 12(1): 41-53.

9. Boonen LHHM, Laske-Aldershof T, Schut FT. Switching health insurers: the role of price, quality and consumer information search. European Journal of Health Economics. 2016; 17(3): 339-53.

10. Astuti HJ, Nagase K. Patient loyalty to health care organizations: Strengthening and weakening (satisfaction and provider switching). Journal of Medical Marketing. 2014; 14(4): 191-200.

11. Keaveney SM. Customer switching behavior in service industries: An exploratory study. Journal of Marketing. 1995; 59(2): 71-82.

12. Halwi S. Preferensi pemanfaatan fasilitas kesehatan tingkat pertama (FKTP) oleh peserta BPJS Mandiri di Kecamatan Banda Sakti Kota Lhokseumawe Tahun 2016 (tesis) [Preferences of utilizing primary health care services among self paid participants of BPJS in Banda Sakti Sub-district, Lhokseumawe City 2016 (thesis)]. Medan: Universitas Sumatera Utara; 2016.

13. Adriana N, Wulandari LPL, Duarsa DP. Akses pelayanan kesehatan berhubungan dengan pemanfaatan fasilitas persalinan yang memadai di Puskesmas Kawangu [Access to health services is associated with the utilization of adequate obstetrics facilities at Kawangu Public Health Center]. Public Health and Preventive Medicine Archive. 2014; 2(2): 175-80.
14. Ministry of Health of Indonesia. Keputusan Menteri Kesehatan Republik Indonesia Nomor: 129/Menkes/SK/ II/2008 Tentang Standar Pelayanan Minimal Rumah Sakit [The Indonesia Ministry of Health Regulation No: 129/ Menkes/SK/II/2008 on The Hospital Minimum Services Standard]. Jakarta; 2008.

15. Ansell D, Crispo JAG, Simard B, Bjerre LM. Interventions to reduce wait times for primary care appointments: a systematic review. BMC Health Services Research. 2017; 17(1): 1-9.

16. Pena MM, da Silva EMS, Tronchin DMR, Melleiro MM. The use of the quality model of Parasuraman, Zeithaml and Berry in health services. Revista da Escola de Enfermagem da USP. 2013; 47(5): 1227-32.

17. Ristiani IY. Pengaruh sarana prasarana dan kualitas pelayanan terhadap kepuasan pasien (studi pada pasien rawat jalan Unit Poliklinik IPDN Jatinangor) [The influence of facilities and services quality to patients' satisfaction (a study among outpatients at Polyclinic Unit of the Jatinangor Institute of Domestic Governance)]. Coopetition. 2017; 8(2): 155-66.

18. Warda A, Junaid, Fachlevy AF. Hubungan persepsi mutu pelayanan dengan tingkat kepuasan pasien Puskesmas Perumnas di Kota Kendari tahun 2016 [The association between quality of services with the patients' satisfaction at Perumnas Public Health Center in Kendari City 2016]. Jurnal Ilmiah Mahasiswa Kesehatan Masyarakat Unsyiah. 2016;123:1-10.

19. Transyah $\mathrm{CH}$, Toni J. Hubungan penerapan komunikasi terapeutik perawat dengan kepuasan pasien [The association between therapeutic communication implementation of nurses with patients' satisfaction]. Jurnal Endurance. 2018;3(1):88.

20. Ha JF, Longnecker N. Doctor-patient communication: a review. The Ochsner Journal. 2010; 10(1): 38-43.

21. Zainun, Lubis S, Lubis L. The Use of therapeutic communication symbol to motivate patient's healing. Journal of Humanities and Social Science. 2017; 22(7): 55-63.

22. Fourianalistyawati E. Komunikasi yang relevan dan efektif antara dokter dan pasien [Relevant and effective communication between doctor and patient]. Jurnal Psikogenesis. 2012; 1(1): 82-7.

23. Napirah MR, Herwanto, Windasar YA. Hubungan komunikasi dokter dengan kepuasan pasien di ruang rawat inap Rumah Sakit Umum (RSU) Anutapura Palu [The association between doctor's communication with patients' satisfaction at inpatient wards of Palu Anutapura General Hospital]. Jurnal Preventif. 2016; 7(2): 1-7.

24. Lu T, Xu YC, Wallace S. Internet usage and patient's trust in physician during diagnoses: A knowledge power perspective. Journal of the Association for Information Science and Technology. 2018; 69(1): 110-20.

25. Tumiwa NN, Yamlean PV, Citraningtyas G. Pelayanan informasi obat terhadap kepatuhan minum obat pasien geriatri di instalasi rawat inap RSUP Prof. Dr. R.D Kandou Manado [Drug information services and medication adherence among geriatric patients at inpatient wards Prof. Dr. R.D Kandou Hospital in Manado]. Jurnal Ilmiah Farmasi. 2014;3(3):310-5.

26. Musaraj A, Musaraj A, Dervishi A. Pharmaco-economics analysis, as a strategy on facilitating choices between health and non-health programs in the establishment of the national health care system. Alexandria Journal of Medicine. 2014; 50(1): 1-6.

27. Kartini W. Pengaruh pelaksanaan kebijakan tentang puskesmas dan dukungan sarana prasarana terhadap manajemen pelayanan kesehatan untuk meningkatkan produktivitas kerja [The influence of policy implementation on public health center and facilities support to health service management in order to increase work productivity]. Jurnal Publik. 2017;11(2):146-56. 
28. Mujiati M, Yuniar Y. Ketersediaan sumber daya manusia kesehatan pada fasilitas kesehatan tingkat pertama dalam era Jaminan Kesehatan Nasional di delapan KabupatenKota di Indonesia [The availability of human resources in health at primary health services in the era of National Health Insurance in eight districts/cities in Indonesia]. Media Penelitian dan Pengembangan Kesehatan. 2017; 26(4): 201-10.

29. Anggraeny C. Inovasi pelayanan kesehatan dalam meningkatkan kualitas pelayanan di Puskesmas Jagir Kota Surabaya [Innovation of health services in increasing the services quality at Jagir Public Health Center Surabaya City]. Kebijakan dan Manajemen Publik. 2013;1:85-93.
30. Indrayathi PA, Mulyawan KH, Dewi PNT. Pemetaan berdasarkan lokasi dan jumlah pesaing puskesmas perawatan di Kabupaten Gianyar yang berstatus BLUD sebagai dasar penyusunan strategis bisnis [Mapping of inpatient public health center with BLUD status based on location and number of competitors in Gianyar District as the basic of business strategic planning]. Archives of Community Health. 2016; 3(1): 56-64.

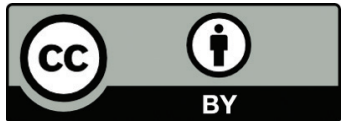

This work is licensed under a Creative Commons Attribution 